\title{
An Assessment of Fungicide Benefits for the Control of Fungal Diseases of Processing Tomatoes in New York and New Jersey
}

H. R. Dillard, Cornell University, New York State Agricultural Experiment Station, Department of Plant Pathology, Geneva 14456; S. A. Johnston, Rutgers Research \& Development Center, Bridgeton, NJ 08302; A. C. Cobb, Cornell University, New York State Agricultural Experiment Station, Department of Plant Pathology, Geneva 14456; and G. H. Hamilton, Rutgers University, New Brunswick, NJ 08903

\begin{abstract}
Dillard, H. R., Johnston, S. A., Cobb, A. C., and Hamilton, G. H. 1997. An assessment of fungicide benefits for the control of fungal diseases of processing tomatoes in New York and New Jersey. Plant Dis. 81:677-681.

Concurrent studies on the benefits of fungicide use for control of fungal diseases of processing tomatoes were conducted in New York and New Jersey in 1993 and 1994. Fungicides (chlorothalonil at $2.5 \mathrm{~kg} / \mathrm{ha}$ or mancozeb at $1.68 \mathrm{~kg} / \mathrm{ha}$ ) were applied at 7-, 10-, or 14-day intervals to processing tomatoes for control of anthracnose caused by Colletotrichum coccodes, early blight caused by Alternaria solani, and Septoria leaf spot caused by Septoria lycopersici. The New Jersey trial included an additional treatment using the disease-warning system TOMCAST. All fungicide treatments significantly reduced foliar disease severity (in New York) and anthracnose incidence (New York and New Jersey) in the 2 years of study. Yield of usable fruit was significantly increased by all fungicide treatments with the exception of the TOM-CAST treatment using the cultivar Brigade in 1994 in New Jersey. In New York, usable yield and financial benefit were consistently the highest in plots treated with chlorothalonil on a 7-day interval. In New Jersey, the highest usable yields and the greatest financial benefits occurred in the chlorothalonil 7- and 10-day interval treatments in 1993. At both locations, the yield and financial benefit associated with the fungicide treatments was primarily due to suppression of anthracnose and other fruit rots. Suppression of foliar diseases was less important.
\end{abstract}

Processing tomatoes (Lycopersicon esculentum Mill.) comprise a small but financially significant acreage of vegetables grown in the northeastern United States (12). Disease management strategies vary with the grower and are influenced by the quality standards imposed by the processing companies. Foliar and fruit diseases are particularly troublesome in New York and New Jersey because frequent rainfall, warm temperatures, and high relative humidity during the growing season promote disease development $(2-4,6,12)$. Processing tomatoes have additional vulnerability to disease because they are machine-harvested after the majority of the fruit is mature. Early maturing fruit that contract disease are an additional source of inoculum for later maturing fruit. Disease management practices must prevent the rate of fruit rotting from exceeding the rate of fruit ripening.

One of the most destructive diseases of processing tomatoes is anthracnose, caused by Colletotrichum coccodes (Wallr.) S.J.

Corresponding author: H. R. Dillard

E-mail: hrd1@cornell.edu

Accepted for publication 21 March 1997.

Publication no. D-1997-0425-05R

(C) 1997 The American Phytopathological Society
Hughes $(2,4,9,11,14,20)$. C. coccodes can infect both green and red fruit, but symptoms are expressed only on mature (red) fruit (4). The fungus sporulates on infected fruit and can result in an unacceptable mold count in the processed product. Tomato processors restrict the proportion of fruit with anthracnose to 3 to $5 \%$. Alternaria solani Sorauer (cause of early blight) and Septoria lycopersici Speg. (cause of Septoria leaf spot) produce circular lesions on leaves, petioles, and stems. Both organisms induce premature defoliation of the tomato plants, which results in suppressed yields $(1,6,8,16)$.

Various cultural practices, such as crop rotation, cover cropping, and the use of disease-free seed, are recommended to reduce disease development in processing tomatoes. Plastic and straw mulches, combined with staking and tying tomato plants, have been shown to reduce disease incidence in fresh market tomatoes $(7,21)$; however, these practices are not feasible in processing tomato systems. In New York and New Jersey, four to eight fungicide applications per season are needed to achieve economic control of foliar and fruit pathogens in processing tomatoes (12). Four broad-spectrum fungicides, chlorothalonil, maneb, mancozeb, and ziram, are currently registered in New York and New Jersey for this use. Processors will accept tomato fruit treated with chlorothalonil and ziram, but some will not accept tomatoes treated with mancozeb or maneb. Chlorothalonil is the primary fungicide used on tomatoes grown in New York and New Jersey because it consistently provides acceptable levels of control of anthracnose and early blight $(5,14,15,17)$.

The goal of this project was to quantify the benefits of the fungicides (mancozeb and chlorothalonil) used in processing tomato production. The data will be used in benefits analyses compiled by the $\mathrm{Na}$ tional Agricultural Pesticide Impact Assessment Program (NAPIAP). Our objectives were to assess disease control and financial benefits as influenced by different fungicide application intervals. Portions of this research were previously reported (13).

\section{MATERIALS AND METHODS}

New York location. All trials were conducted in field 21 at the Vegetable Research Farm in Geneva. The field is naturally infested with $C$. coccodes, $A$. solani, and $S$. lycopersici and is regularly planted with tomatoes to maintain high pathogen populations. The soil type is Honeyoye fine sandy loam, $\mathrm{pH} 6.5$ to $7.2,2.1 \%$ organic matter, and is described as a deep, well-drained soil formed in high lime glacial till. Rainfall and irrigation by month totaled $7.0 \mathrm{~cm}$ in May, $6.9 \mathrm{~cm}$ in June, 11.4 $\mathrm{cm}$ in July, $4.5 \mathrm{~cm}$ in August, and $3.6 \mathrm{~cm}$ to 9 September $1993 ; 6.0 \mathrm{~cm}$ in May, 10.7 $\mathrm{cm}$ in June, $3.5 \mathrm{~cm}$ in July, $16.4 \mathrm{~cm}$ in August, and $0.5 \mathrm{~cm}$ to 7 September 1994.

In 1993, tomatoes (cv. Early Pear) were seeded in potting mix in the greenhouse on 15 and 16 April and transplanted on 18 May. Seven treatments were arranged in a randomized complete block design with six replications per treatment. Each replicate plot was $9 \mathrm{~m}$ long on $1.5-\mathrm{m}$ centers. Plants within the row were spaced approximately 23 to $28 \mathrm{~cm}$ apart. A nonsprayed buffer row was present on each side of the treated rows. Fungicide applications were initiated when the crown fruit were one-third of estimated full size. Three application schedules were used: eight applications at 7-day intervals, six applications at 10-day intervals, and four applications at 14-day intervals. Chlorothalonil (Bravo 720) treatments were applied at the rate of 2.5 $\mathrm{kg} / \mathrm{ha}$, and mancozeb (Penncozeb DF) 
treatments were applied at the rate of 1.68 $\mathrm{kg} / \mathrm{ha}$. All fungicide rates are given as the amount of active ingredient per hectare. Treatments were applied with a $\mathrm{CO}_{2}$-pressurized backpack sprayer delivering 468 liters/ha at $345 \mathrm{kPa}$. Three flat fan nozzles (Spraying Systems 8003) were configured on the boom, with one positioned over the top of the row and one nozzle positioned on each side of the row on $22.5-\mathrm{cm}$ drop pipes. A nonsprayed control plot constituted the seventh treatment. The experiment was repeated in 1994 using the same tomato cultivar, which was seeded in the greenhouse on 14 and 15 April and transplanted 23 May.

Foliar diseases were rated periodically using the 1 to 6 scale recommended by CSRS/NAPIAP, where $1=0,2=1$ to 10,3 $=11$ to $30,4=31$ to $70,5=71$ to 90 , and $6=91$ to $100 \%$ leaf surface area diseased. Ethephon (Ethrel, $1.3 \mathrm{~kg}$ a.i./ha) was applied on 23 August 1993 and 23 August 1994 to accelerate fruit ripening. Tomato fruit were hand harvested from $3 \mathrm{~m}$ of row in each replicate plot and evaluated 7, 8, and 9 September 1993, and 6 and 7 September 1994. Incidence of anthracnose and other fruit rots was recorded, and yield of usable fruit was determined. The usable yield category was defined as all tomatoes that were disease-free and red in color.

Disease progress curves were constructed for each foliar disease present in the trials. Disease severity was calculated using the midpoint percentage value in the severity scale for all plants of each replicate plot. Final foliar disease severity, fruit rot incidence, and yield data were analyzed by analysis of variance, and Fisher's protected LSD was used to separate means $(P$ $<0.05)$. The financial benefits achieved under each fungicide regime were estimated by comparing the values with the nonsprayed control and by subtracting production costs from the gross value of the crop.

New Jersey location. The experiment was conducted in a field with a history of continuous tomato production at the Rutgers Research and Development Center in Bridgeton. The soil type was described as an Aura loam, $\mathrm{pH}$ 6.5. Rainfall and irrigation by month totaled $10.2 \mathrm{~cm}$ in June, 19.5 $\mathrm{cm}$ in July, $5.1 \mathrm{~cm}$ in August, and $6.6 \mathrm{~cm}$ in September 1993; $6.4 \mathrm{~cm}$ in June, 35.1 $\mathrm{cm}$ in July, $23.1 \mathrm{~cm}$ in August, and $8.9 \mathrm{~cm}$ in September 1994.

In 1993, 8-week-old tomato plants (cv. Brigade) were transplanted on 9 June. Five treatments were replicated six times in a randomized complete block design. Each replicate plot was $4.6 \mathrm{~m}$ long on $1.5-\mathrm{m}$ centers. Each plot contained 10 plants spaced $43 \mathrm{~cm}$ apart. A nonsprayed buffer row was present on each side of the treated rows. Fungicide applications were initiated when the crown fruit were one-third of estimated full size. Four application schedules were used: eight applications at 7-day intervals, six applications at 10-day intervals, four applications at 14-day intervals, and applications according to the TOMCAST (10) forecasting system. In the TOM-CAST treatment, weather data were accumulated with a Sensor Instruments (Concord, NH) Field Monitor, and the first fungicide application was applied after 45 disease severity values (DSV) had accumulated. Additional applications were made after 25 DSV had accumulated. Four fungicide applications were made in the TOM-CAST treatments. Chlorothalonil (Bravo 720) was applied at the rate of 2.5 $\mathrm{kg}$ a.i./ha. Fungicides were applied with a tractor-drawn boom sprayer that delivered 870 liters/ha at $1,724 \mathrm{kPa}$. The boom contained three hollow cone nozzles (D4-25, disk core) arranged with a drop nozzle on each side of the row and a nozzle on top of the row. A nonsprayed control plot constituted the fifth treatment. The experiment was repeated in 1994 using the same tomato cultivar transplanted on 7 June.

Foliar diseases were rated periodically using the previously described CSRS/ NAPIAP scale. Tomato fruit were hand harvested and evaluated on 16 September 1993 and 21 September 1994. All fruit from four consecutive plants in the middle of each plot were removed and separated into ripe and nonripe categories. All fruit also were evaluated for the presence of buckeye rot (Phytophthora nicotianae Breda de Haan var. parasitica (Dastur)

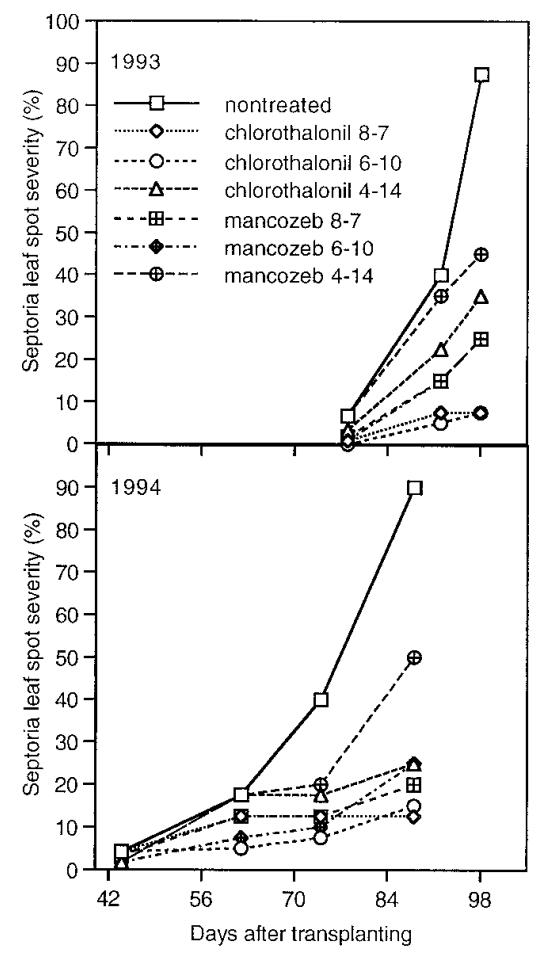

Fig. 1. Disease progress curves of Septoria leaf spot severity on processing tomatoes grown in New York in 1993 and 1994. Each value is the mean of six replicate plots. Final foliar severity $\operatorname{LSD}(P=0.05)$ in $1993=11$, in $1994=10$.
G.M. Waterhouse), and only ripe fruit were evaluated for the incidence of anthracnose. Yield was determined by combining the weight of healthy fruit in the nonripe and ripe categories. Fruit rot incidence and yield data were analyzed by analysis of variance, and LSD was used to separate means $(P<0.05)$. Financial benefits achieved under each fungicide regime were estimated by comparing with the nonsprayed control and by subtracting production costs from the gross value of the crop.

\section{RESULTS}

New York location. In 1993, Septoria leaf spot and early blight severity were high and resulted in premature defoliation of the nontreated plants (Figs. 1 and 2). In 1994, early blight severity was low and Septoria leaf spot severity was high. Final foliar severity of early blight in the nonsprayed control plots was 75 and $5 \%$ in 1993 and 1994, respectively. Final foliar severity of Septoria leaf spot in the nonsprayed control plots was 88 and $90 \%$ in 1993 and 1994, respectively. Foliar fungicides significantly reduced final severity of early blight in 1993 and Septoria leaf spot in both years (Figs. 1 and 2). Final foliar disease severity was lowest in the treatments where chlorothalonil was applied at 7- or 10-day intervals. Four applications of chlorothalonil applied on 14-day intervals resulted in disease levels similar to those provided by mancozeb at 7-, 10-, or 14-day

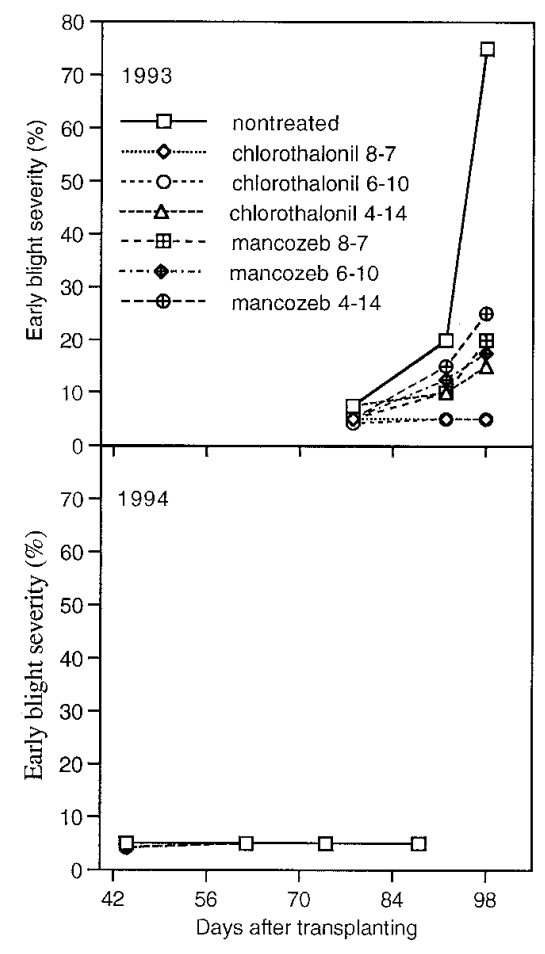

Fig. 2. Disease progress curves of early blight severity on processing tomatoes grown in New York in 1993 and 1994. Each value is the mean of six replicate plots. Final foliar severity LSD $(P=0.05)$ in $1993=11$, in $1994=$ no significant difference. 
intervals. Bacterial speck (Pseudomonas syringae pv. tomato) and spot (Xanthomonas campestris pv. vesicatoria) were present at low levels in both years (data not shown).

All fungicide treatments significantly reduced the incidence of anthracnose in both years of the study (Table 1). Fungicide applications significantly reduced incidence of other fruit rots except in the mancozeb 10-day interval (1993) and the mancozeb 14-day interval (1993 and 1994) treatments. Other fruit rots were identified as cottony leak (Pythium spp.), sour rot (Geotrichum candidum Link), and soil rot (Rhizoctonia solani Kühn). In both years, usable yield was significantly increased by all fungicide treatments, with the highest yield in the chlorothalonil 7-day interval treatment.
All fungicide treatments resulted in a financial benefit at harvest (Table 2). Yields were higher in 1994 and resulted in greater financial returns associated with fungicide treatments. The highest financial returns were associated with applications of chlorothalonil at 7-day intervals. Financial loss occurred in the nontreated plots.

New Jersey location. In 1993, dry weather prevented development of foliar diseases. In 1994, foliar diseases did not appear until late in the season, and bacterial spot accounted for the majority of defoliation. There were no significant differences in defoliation among treatments (data not shown).

All fungicide treatments resulted in a significant reduction in anthracnose in both years (Table 3). Buckeye rot incidence was low, and there were no significant differences among treatments. All fungicide treatments resulted in significantly greater usable yields, with the exception of the TOM-CAST treatment using the cultivar Brigade in 1994.

Chlorothalonil applied at 7-day intervals consistently resulted in a financial benefit at harvest (Table 4). Financial loss occurred in the nontreated plots.

\section{DISCUSSION}

In New York and New Jersey, fungicide applications to processing tomatoes provided significant disease control and resulted in significant financial benefits. In New York, chlorothalonil applications at 7or 10-day intervals consistently provided significant control of foliar fungal patho-

Table 1. Effect of fungicide applications on percentage of fruit with anthracnose and other fruit rots, and yield of processing tomatoes grown in New York in 1993 and 1994

\begin{tabular}{|c|c|c|c|c|c|c|c|c|c|}
\hline \multirow[b]{2}{*}{ Treatment $^{\mathbf{a}}$} & \multirow{2}{*}{$\begin{array}{l}\text { Application } \\
\text { interval }\end{array}$} & \multicolumn{2}{|c|}{ Anthracnose (\%) } & \multicolumn{2}{|c|}{ Other $\operatorname{rot}(\%)$} & \multicolumn{2}{|c|}{ Total yield (t/ha) } & \multicolumn{2}{|c|}{ Usable yield (t/ha) } \\
\hline & & 1993 & 1994 & 1993 & 1994 & 1993 & 1994 & 1993 & 1994 \\
\hline Nontreated & & 27.0 & 21.4 & 6.7 & 10.0 & 66.1 & 64.6 & 42.1 & 42.2 \\
\hline Chlorothalonil & 8 sprays, 7 -day & 2.9 & 0.4 & 3.8 & 5.5 & 85.6 & 104.0 & 79.1 & 96.0 \\
\hline Chlorothalonil & 6 sprays, 10 -day & 2.8 & 0.6 & 3.6 & 5.6 & 78.7 & 93.7 & 73.3 & 84.8 \\
\hline Chlorothalonil & 4 sprays, 14 -day & 10.9 & 2.1 & 4.4 & 6.4 & 79.1 & 90.6 & 65.0 & 81.6 \\
\hline Mancozeb & 8 sprays, 7 -day & 7.4 & 1.0 & 3.6 & 4.3 & 84.1 & 96.4 & 73.5 & 89.5 \\
\hline Mancozeb & 6 sprays, 10 -day & 10.3 & 1.7 & 5.1 & 5.1 & 81.1 & 86.3 & 66.8 & 79.2 \\
\hline Mancozeb & 4 sprays, 14 -day & 15.5 & 6.2 & 5.6 & 7.4 & 74.2 & 83.4 & 55.6 & 70.4 \\
\hline \multicolumn{2}{|l|}{$\operatorname{LSD}(P=0.05)$} & 6.5 & 5.4 & 2.1 & 2.7 & 10.3 & 10.5 & 11.2 & 11.9 \\
\hline
\end{tabular}

${ }^{a}$ Chlorothalonil rate was $2.5 \mathrm{~kg}$ a.i./ha, and mancozeb rate was $1.68 \mathrm{~kg}$ a.i./ha.

Table 2. Financial benefits associated with fungicide regimes used to control fungal diseases on processing tomatoes grown in New York in 1993 and 1994

\begin{tabular}{|c|c|c|c|c|c|c|c|c|c|}
\hline \multirow[b]{2}{*}{ Treatment } & \multirow{2}{*}{$\begin{array}{l}\text { Application } \\
\text { interval }\end{array}$} & \multicolumn{2}{|c|}{ Value $(\$ / h a)^{a}$} & \multicolumn{2}{|c|}{ Fung. cost $(\$ / h a)^{b}$} & \multicolumn{2}{|c|}{$\begin{array}{l}\text { Value less fung. } \\
\text { cost }(\$ / h a)\end{array}$} & \multicolumn{2}{|c|}{$\begin{array}{l}\text { Value less other } \\
\text { prod. cost }(\$ / h a)^{c}\end{array}$} \\
\hline & & 1993 & 1994 & Labor cost & Matl. cost & 1993 & 1994 & 1993 & 1994 \\
\hline Nontreated & & 2,825 & 2,972 & & & 2,825 & 2,972 & -308 & -161 \\
\hline Chlorothalonil & 8 sprays, 7 -day & 5,308 & 6,760 & 130 & 155 & 5,023 & 6,475 & $+1,890$ & $+3,342$ \\
\hline Chlorothalonil & 6 sprays, 10 -day & 4,919 & 5,972 & 98 & 117 & 4,704 & 5,757 & $+1,571$ & $+2,624$ \\
\hline Chlorothalonil & 4 sprays, 14 -day & 4,362 & 5,746 & 65 & 78 & 4,219 & 5,603 & $+1,086$ & $+2,470$ \\
\hline Mancozeb & 8 sprays, 7 -day & 4,933 & 6,303 & 130 & 46 & 4,757 & 6,127 & $+1,624$ & $+2,994$ \\
\hline Mancozeb & 6 sprays, 10 -day & 4,483 & 5,577 & 98 & 34 & 4,351 & 5,445 & $+1,218$ & $+2,312$ \\
\hline Mancozeb & 4 sprays, $14-$ day & 3,731 & 4,958 & 65 & 23 & 3,643 & 4,870 & +510 & $+1,737$ \\
\hline
\end{tabular}

${ }^{a}$ Usable yield (t/ha) $\times$ price per $\mathrm{t}(\$ 67.11$ in $1993, \$ 70.42$ in 1994$)$. Price reflects deductions for trucking $\$ 26.45 / t$ and a voluntary contribution of $\$ 0.11 / t$ to the New York State Tomato Research Association.

${ }^{\mathrm{b}}$ Fungicide application costs (same in 1993 and 1994). Labor $=\$ 16.30$ per ha $\times$ number of applications. Material costs: chlorothalonil (Bravo $720,2.5 \mathrm{~kg}$ a.i./ha) $=\$ 19.42 \times$ number of applications; mancozeb (Penncozeb DF, $1.68 \mathrm{~kg}$ a.i./ha) $=\$ 5.74 \times$ number of applications.

${ }^{\mathrm{c}}$ Other estimated production costs from planting through harvest $(\$ 3,133 / \mathrm{ha})$.

Table 3. Effect of fungicide applications on percentage of fruit with anthracnose and other fruit rots, and yield of processing tomatoes grown in New Jersey in 1993 and 1994

\begin{tabular}{|c|c|c|c|c|c|c|c|c|c|c|c|}
\hline \multirow[b]{3}{*}{ Treatment $^{\mathrm{a}}$} & \multirow{3}{*}{$\begin{array}{l}\text { Application } \\
\text { interval }\end{array}$} & \multicolumn{6}{|c|}{ Fruit rots (\%) } & \multirow{2}{*}{\multicolumn{2}{|c|}{ Total yield (t/ha) }} & \multirow{2}{*}{\multicolumn{2}{|c|}{ Usable yield (t/ha) }} \\
\hline & & \multicolumn{2}{|c|}{ Anthracnose } & \multicolumn{2}{|c|}{ Buckeye } & \multicolumn{2}{|c|}{ Total } & & & & \\
\hline & & 1993 & 1994 & 1993 & 1994 & 1993 & 1994 & 1993 & 1994 & 1993 & 1994 \\
\hline Nontreated & & 54.4 & 71.3 & 10.8 & 5.0 & 50.6 & 50.2 & 38.3 & 40.1 & 19.1 & 19.2 \\
\hline Chlorothalonil & 8 sprays, 7 -day & 11.3 & 15.7 & 4.6 & 7.3 & 14.4 & 14.9 & 53.5 & 56.5 & 45.3 & 48.1 \\
\hline Chlorothalonil & 6 sprays, 10 -day & 12.9 & 24.8 & 4.0 & 5.1 & 14.8 & 22.2 & 53.0 & 51.1 & 44.6 & 40.3 \\
\hline Chlorothalonil & 4 sprays, 14 -day & 18.6 & 38.7 & 5.1 & 5.1 & 20.4 & 25.2 & 43.4 & 45.3 & 33.8 & 35.2 \\
\hline Chlorothalonil & TOM-CAST & 17.8 & 28.6 & 7.0 & 7.7 & 21.0 & 27.1 & 50.9 & 41.2 & 39.5 & 28.8 \\
\hline $\operatorname{LSD}(\mathrm{P}=0.05)$ & & 9.5 & 18.3 & $\mathrm{NS}^{\mathrm{c}}$ & NS & 7.6 & 16.7 & 12.4 & NS & 10.1 & 13.4 \\
\hline
\end{tabular}

${ }^{\text {a }}$ Chlorothalonil rate was $2.5 \mathrm{~kg}$ a.i./ha.

${ }^{\mathrm{b}}$ Forecasting system used to schedule fungicide applications.

${ }^{\mathrm{c}}$ Not significant. 
Table 4. Financial benefits associated with fungicide regimes used to control fungal diseases on processing tomatoes grown in New Jersey in 1993 and 1994

\begin{tabular}{|c|c|c|c|c|c|c|c|c|c|}
\hline \multirow[b]{2}{*}{ Treatment } & \multirow{2}{*}{$\begin{array}{l}\text { Application } \\
\text { interval }\end{array}$} & \multicolumn{2}{|c|}{ Value $(\$ / h a)^{a}$} & \multicolumn{2}{|c|}{ Fung. cost $(\$ / h a)^{b}$} & \multicolumn{2}{|c|}{ Value less fung. cost (\$/ha) } & \multicolumn{2}{|c|}{ Value less other prod. cost $(\$ / \mathrm{ha})^{\mathrm{c}}$} \\
\hline & & 1993 & 1994 & Labor cost & Matl. cost & 1993 & 1994 & 1993 & 1994 \\
\hline Nontreated & & 1,579 & 1,579 & $\ldots$ & $\ldots$ & 1,579 & 1,579 & $-1,554$ & $-1,554$ \\
\hline Chlorothalonil & 8 sprays, 7 -day & 3,745 & 3,985 & 130 & 139 & 3,476 & 3,716 & +343 & +583 \\
\hline Chlorothalonil & 6 sprays, 10 -day & 3,687 & 3,340 & 98 & 105 & 3,484 & 3,137 & +351 & +4 \\
\hline Chlorothalonil & 4 sprays, 14 -day & 2,794 & 2,910 & 65 & 70 & 2,659 & 2,775 & -474 & -358 \\
\hline Chlorothalonil & TOM-CAST & 3,265 & 2,373 & 65 & 70 & 3,130 & 2,238 & -3 & -895 \\
\hline
\end{tabular}

a Usable yield (t/ha) $\times$ price per $\mathrm{t}(\$ 82.67)$.

${ }^{\mathrm{b}}$ Fungicide application costs (same in 1993 and 1994). Labor $=\$ 16.30$ per ha $\times$ number of applications. Material costs: chlorothalonil (Bravo $720,2.5$ kg a.i./ha) $=\$ 17.42 \times$ number of applications.

c Other estimated production costs from planting through harvest $(\$ 3,133 / \mathrm{ha})$.

${ }^{\mathrm{d}}$ Forecasting system used to schedule fungicide applications.

gens and control of anthracnose at a level acceptable to tomato processors $(<3 \%)$ (Table 2). Although significant anthracnose control was achieved at the New Jersey location, the incidence of anthracnose remained at levels unacceptable to tomato processors $(>5 \%)$. The higher-than-acceptable levels of anthracnose at the New Jersey location were due in part to (i) use of a field with a history of tomato production, which resulted in levels of anthracnose higher than most growers would experience because tomato growers rotate fields each year; (ii) the use of a very anthracnose susceptible cultivar (Brigade); (iii) planting late in the season when environmental conditions were more favorable for anthracnose development; and (iv) hand harvesting all fruit from sampled plants, whereas in commercial production, many of the anthracnose-infected fruit are discarded during mechanical harvest and grading operations. At the New York and New Jersey locations, incidence of anthracnose and other fruit rots was sufficiently high to reduce the usable yield to a level where a financial loss was projected in the nontreated plots.

The higher yields in New York were likely the result of warm weather conditions and timely rainfall. The yields obtained in this trial are higher than the New York state average of $56 \mathrm{t} / \mathrm{ha}$ for processing tomatoes. Growers have determined that they need to achieve minimum yields of 49 t/ha to break even financially. Average yields result in average estimate net profits of $\$ 500 /$ ha.

The yield and financial benefits associated with the fungicide treatments were due primarily to suppression of anthracnose and other fruit rots. The estimated financial benefits in this study are higher than most growers achieve because of price deductions that we were unable to estimate in our trials. For example, in New York there are four categories of deductions: fruit rots including anthracnose (limit 6\%), color (limit $8 \%$ under color), structural defects (limit 8\%), and matter other than tomato (MOT, limit 9\%). Our study only addresses deductions for fruit rots.

In summary, the studies conducted in New York and New Jersey showed that fungicide use on processing tomatoes results in a significant reduction in foliar fungal disease severity, a significant reduction in anthracnose and other fruit rot incidence, and a significant increase in usable yield. Disease control increases financial benefits for New York and New Jersey processing tomato producers. Similar results were observed in Florida when target spot and bacterial spot were managed with protectant fungicides (19) and in South Carolina when early blight was controlled with fungicides (16). Although fixed fungicide application schedules were used in this study, some growers are using disease forecasting systems, such as FAST and TOM-CAST $(9,10,14-16,18,22)$. The primary benefit of using forecasting systems is that the fungicides are applied at the optimum time for disease control, and the additional benefits include reduced pesticide use and associated costs (10). However, the use of TOM-CAST at the New Jersey location did not result in a financial benefit compared with the use of chlorothalonil applied on a 7- or 10-day schedule. In the South Carolina study using fresh market tomatoes, plots receiving fungicides had less early blight than nonsprayed control plots, but crop value and net return were not significantly affected by weekly or TOM-CAST fungicide application schedules, or by the use of an early blight tolerant cultivar (16). Foliar symptoms of early blight were not severe enough to reduce usable yield in the South Carolina study or in our study. Since fruit rots had the greatest affect on yield in our study, perhaps the use of TOM-CAST with processing tomato cultivars possessing greater tolerance to anthracnose would result in more financial benefit.

\section{ACKNOWLEDGMENTS}

We thank the North East Pesticide Impact Assessment Program and the New York State Tomato Research Association for providing funds to support this project. We thank John Martini and Bill Garman for timely advice.

\section{LITERATURE CITED}

1. Brammall, R. A. 1993. Effect of foliar fungicide treatment on early blight and yield of fresh market tomato in Ontario. Plant Dis. 77:484-488.

2. Dillard, H. R. 1987 . Tomato anthracnose.
Cornell Cooperative Extension. Vegetable Crops Fact Sheet. p. 735.70.

3. Dillard, H. R. 1989. Effect of temperature, wetness duration, and inoculum density on infection and lesion development of Colletotrichum coccodes on tomato fruit. Phytopathology 79:1063-1066.

4. Dillard, H. R. 1992. Colletotrichum coccodes: The pathogen and its hosts. Pages 225-236 in: Colletotrichum: Biology, Pathology and Control. J. A. Bailey and M. J. Jeger, eds. CAB International, Wallingford, UK.

5. Dillard, H. R., Cobb, A. C., Hoffman, D. J., McCormick, K. E., Ntahimpera, N., and Seem, J. E. 1996. Evaluation of fungicides for control of foliar and fruit diseases of fresh market tomatoes grown on bare ground or straw mulch, 1995. Fungic. Nematicide Tests 51:155.

6. Elmer, W. H., and Ferrandino, F. J. 1995. Influence of spore density, leaf age, temperature, and dew periods on Septoria leaf spot of tomato. Plant Dis. 79:287-290.

7. Estes, E. A., Skroch, W. A., Konsler, T. R., Shoemaker, P. B., and Sorensen, K. A. 1985. Net economic values of eight soil management practices used in stake tomato production. J. Am. Soc. Hortic. Sci. 110(6):812816.

8. Ferrandino, F. J., and Elmer, W. H. 1992. Reduction in tomato yield due to Septoria leaf spot. Plant Dis. 76:208-211.

9. Fulling, B. A., Tigchelaar, E. C., and Latin, R. X. 1992. Integration of resistance with a weather-based fungicide scheduling program for control of anthracnose on processing tomatoes. (Abstr.) Phytopathology 82:991-992.

10. Gleason, M. L., MacNab, A. A., Pitblado, R. E., Ricker, M. D., East, D. A., and Latin, R. X. 1995. Disease-warning systems for processing tomatoes in eastern North America: Are we there yet? Plant Dis. 79:113121.

11. Illman, W. I., Ludwig, R. A., and Farmer, J. 1959. Anthracnose of canning tomatoes in Ontario. Can. J. Bot. 37:1237-1246.

12. Johnston, S. A. 1991. Fungicide Benefits Assessment - Vegetables, East. National Agricultural Pesticide Impact Assessment Program, Washington, DC.

13. Johnston, S. A., and Dillard, H. R. 1994. Assessment of fungicide benefits for the control of anthracnose on processing tomatoes in the northeast, 1993. Proc. Natl. Integr. Pest Manage. Symp./Workshop 2:127.

14. Johnston, S. A., and Phillips, J. R. 1994. Evaluation of fungicides for the control of anthracnose on processing tomatoes, 1993. Fungic. Nematicide Tests 49:162.

15. Johnston, S. A., and Phillips, J. R. 1995 Evaluation of fungicides for the control of foliar and fruit diseases of processing tomatoes, 1994. Fungic. Nematicide Tests 50:170.

16. Keinath, A. P., DuBose, V. B., and Rathwell, 
P. J. 1996. Efficacy and economics of three fungicide application schedules for early blight control and yield of fresh-market tomato. Plant Dis. 80:1277-1282.

17. Lukens, R. J., and Ou, S. H. 1976. Chlorothalonil residues on field tomatoes and protection against Alternaria solani. Phytopathology 66:1018-1022.

18. Madden, L., Pennypacker, S. P., and MacNab, A. A. 1978. FAST, a forecast system for $A l$ ternaria solani on tomato. Phytopathology
68:1354-1358.

19. Pernezny, K., Datnoff, L. E., Mueller, T., and Collins, J. 1996. Losses in fresh-market tomato production in Florida due to target spot and bacterial spot and the benefits of protectant fungicides. Plant Dis. 80:559-563.

20. Precheur, R. J., Bennett, M. A., Riedel, R. M., Wiese, K. L., and Dudek, J. 1992. Management of fungicide residues on processing tomatoes. Plant Dis. 76:700-702.

21. Steffen, K. L., Dann, M. S., Harper, J. K.,
Fleischer, S. J., Mkhize, S. S., Grenoble, D. W., MacNab, A. A., Fager, K., and Russo, J. M. 1995. Evaluation of the initial season for implementation of four tomato production systems. J. Am. Soc. Hortic. Sci. 120(2):148 156.

22. Zitter, T. A., and Sandlan, K. P. 1990. CUFAST-beta test version: Cornell University forecaster of Alternaria solani on tomato. Plant Pathology Extension Report 90-1. Cornell University, Ithaca, NY. 